\title{
Integrative of Perceived Management Support on Information Technology Innovativeness
}

\author{
ANAS R M LUBBAD
}

\begin{abstract}
Government Information Technology Innovativeness defined as notion of openness to new information technology ideas in the government as an aspect of an organizational culture. In adopting the information technology innovativeness, management support plays a crucial effect. Misunderstood organizational characteristic within information technology innovativeness may generate unrealistic or inaccurate outcomes. Unfortunately, the effect of organizational context is nearly ignored in information technology innovativeness literature. In response, using the Resources based view (RBV) and Diffusion-Innovation-Theory (DIT), this paper argues on the interaction between the influence of organizational characteristic (management support), so as to explain information technology innovativeness. This proposition could improve understanding the information technology innovativeness and help to resolve inconsistency of findings in the literature.
\end{abstract}

Keywords: Management Support; organizational characteristics; information technology innovativeness

DOI: $10.7176 / \mathrm{EJBM} / 13-19-02$

Publication date:October $31^{\text {st }} 2021$

\section{Introduction}

Van der Boor, Oliveira, and Veloso (2014) see that the most advanced countries have realized the problem of innovation in the field of information technology and they are able to deal with the innovation and its implementations and adoption. However, at the level of Middle East countries, they still need to understand how to deal with this problem and seek to resolve it through training and development.

The concept of information technology has become indispensable in performance of individual, organizations, and the government at large. In the contemporary global world, innovation in Information Technology (IT) can assist government in the discharge of its immense functions to its citizen. The United Nations (2017) and the Organisation for Economic Co-operation and Development (OECD) (2011) specify ten core functions of the government. These comprise General public services, Defence, Economic affairs, Housing and community amenities, Public order and safety, Health, Environmental protection, Social protection, Recreation, culture and religion.

This study investigate the level of government information technology innovativeness in local government in Gaza Strip, Palestine, through decision makers and managers by investigating the relationship between management support and government information technology innovativeness.

The key purpose of this research is to examine the determinants for governments' innovativeness of information technologies in the public sector, which have been paid relatively little attention by researchers, notwithstanding their significance in technological advancement in the public sector (Kapoor, Dwivedi, \& Williams, 2014; Rashidi, Begum, Mokhtar, \& Jacqueline, 2014). This research discusses technology innovation in the public sector of the local government in the Gaza Strip, Palestine. These innovations occurred in different governmental institutions' public and governmental routines across the Gaza Strip.

Study significant

This study provides an exclusive theoretical framework intended to assist researchers and practitioners develop a comprehensive understanding of the linkages between Organizational Factors and Information Technology Innovativeness. Therefore, the implication of this study can be divided into two categories, which are theoretical contributions and practical contributions.

This study also contributes to our theoretical understanding of government information technology innovativeness in local government in the Gaza Strip and its implementation, by using the Resource Based View, Contingency and Diffusion Theory to support the theoretical part of the study. The present study is important for a country like Palestine that has witnessed a growing occurrence of this issue, which has led to financial and productivity costs, as remarked by the Ministry of Information Technology in local government in the Gaza Strip (Alisawi, 2014).

All of the studies in the area of information technology innovativeness or information technology intention to adapt or information technology adoption conducted in the business and financial sectors, but this study consider the first information technology innovativeness study in the public sector context.

This study focused on the local government in the Gaza strip. It also used the managers in the local governments. The managers in the local government in the Gaza strip share the same qualities with other managers in the other local governments in Palestine, hence, the respondents serve as good representatives of the entire population of work force in the public sector. 


\section{Organization Innovativeness}

Organization Innovativeness is the notion of openness to new ideas as an aspect of an organizational culture (Venkatesh \& Bala, 2012). In other words, it is the creativeness of an organization in coming up with ideas that promote the development of the organization.

\section{Management support}

Management technology support refers to the degree of managerial and organizational openness of technological change (Cho \& Kim, 2002). This study will define management support as the effect on the Government Information Technology Innovativeness in the local government in Gaza strip - Palestine.

Nowadays governments operate in an environment characterized by the rapid pace of technological change (Shokralla, Spall, Gibson, \& Hajibabaei, 2012). It is essential that governments reinvent themselves, as they face many tests such as the complexity of providing public services and the constant change in the nature of governmental work and publicity within institutions. This change requires management support of government information technology innovativeness (Lewis et al, 2013).

Furthermore, public institutions are looking to improve their managerial methods and goals in line with environmental circumstances by adjusting the organizational culture in line with technology. Given that technology improvement and growth is racing ahead, more and more attention is being paid to the influence of technology on organizational culture (Vaccaro, Jansen, Van Den Bosch, \& Volberda, 2012).

In addition, the role of management appears to be crucial in achieving synergy between the activities and operations in public institutions, because management is an important source to achieve organizational goals. Management is responsible for understanding the organizational principles and values of its employees and workers, in addition to generating synergy and compatibility between them (Manna, 2012; Turban \& Volonino, 2010).

We found that management support is a critical and significant issue in the implementation and adoption of information technology innovation in local government in the Gaza Strip that leads to achieving and maintaining a critical advantage. There is frequent recognition of the dynamic role played by management in identifying and taking advantage of opportunities and making decisions on government information technology innovativeness to add value to public institutions and governments working process (El-Ghorra, 2011; Elenkov, Judge, \& Wright, 2005). The interface between management and innovation has received significant attention by researchers (Kim, Dong Kumar, Vinod Kumar, \& Uma, 2012; Sharma, Srinarayan Rai, \& Arun, 2003; West et al., 2003).

Many studies that examined the relationship between top management and innovation to show that management support positively affects information technology innovation and that there is a positive connection between innovation and governmental initiation (Bowen, Rostami, \& Steel, 2010; Ryan \& Tipu, 2013). The underlying forces of working conditions in evolving countries pose challenges to management, where the necessity for government information technology innovativeness stands out as a main contributing tool to achievement of sustainable benefit for survival in the public sector (Chandiwana, 2013).

Consequently, management plays an essential role in the detection of information technology innovations given a suitable environment, and in making polices that enhance the successful creation and execution of understanding (Mason, 2015).

Many researchers have stated that management support plays an important role in organizational consequences (Agbim, 2013; Chahine \& Goergen, 2013). Further researchers still have recommended that management support have a key role in encouraging the adoption of information technology innovative activities in organizations (Denti \& Hemlin, 2012;Kim et al., 2012Makri \& Scandura, 2010). López Sánchez and SantosVijande (2016) found that there is a relationship between management support and innovativeness. They argue that management support top in term of provision of necessary resources, giving priorities to needs, and actively involved in the delivery of project has impact on innovative service delivery.

\section{Standpoints on the impact of management support of information technology innovativeness}

Government information technology innovativeness is a process whereby directors spread an information technology into a civilian user community (Mergel, 2013). The management support is thought to be critical for information technology innovation implementation success in the public sector (Elbanna, 2013).

Many of the studies have examined the impact of management support on information technology innovation implementation outcomes. It has been found that management support significantly affects technology innovations (Bose \& Luo, 2011), institutional success (Popovič, Hackney, Coelho, \& Jaklič, 2012), progressive use of information technology innovation, and organizational information technology innovation adoption (Venkatesh, Thong, \& Xu, 2012).

These researches differ in their viewpoints relating to the effect of management support, and different findings have been reached. For example, many researches shed light on the effect of management support, 
contending that there are three perspectives relating to the effect of management support on information technology innovativeness (Mergel \& Bretschneider, 2013).

Underlying the information technology innovation background, the management comprises a group of senior managers appointed to oversee the progress of the information technology innovation implementation and adoption. There are three perspectives on management support and reaction to any new change in the public establishment (Mergel \& Bretschneider, 2013). These are examined further below.

\section{Relationship between management support and information technology innovativeness}

Management support establishes the cooperation of individuals answerable to the management of the governmental institution, principally in formulating and executing strategies for change (Chen, Guoquan Tjosvold, Dean Liu, \& Chunhong, 2006). Some researchers have established that a manager's direction can be distinguished from demographic features and from the team's arrangement (Wu \& Liang, 2008). Other research has recommended that the arrangement of the management support has an influence on governmental institution decisions to commit capital for government information technology innovation adoption and implementation (Yigitbasioglu \& Irani, 2015).

The results of research on the reality of any direct connection between management support features and government information technology innovativeness indicate that in earlier works, like that by Wally and Becerra (2001), no connection was found between government information technology innovativeness and management support. Furthermore, studies have identified results in relation to management support (Schechter et al., 2015).

These inconsistencies and the shortage of findings have inspired a new line of thinking alongside Rogers' theory that governmental institution decisions and results cannot be explained by management support alone. Some researchers address other issues that affect government information technology innovation implementation and adoption.

Some authors attribute significance to the conflict that could result from variations in the characteristics of top administration and managers in public institutions and the government, as well as in how they cooperate with one another (Gatautis, 2015).

Given the previous arguments, this study suggests that specific management support guarantees that decision makers will recognise the importance of common understanding for information technology innovation implementation and adoption, exchange of information, and the opportunity to reach a consensus (Michel \& Hambrick, 2002).

Therefore, a suitable level of agreement within management as to the significance of information technology innovation implementation for the government is seen as a need for the support of government information technology innovation implementation and adoption. One of the objectives of this research is investigate the impact of management support on government information technology innovation implementation and adoption.

\section{Research Methodology}

This study focuses on examining the determinant of the information technology innovativeness and adoption in the local government in Gaza strip - Palestine. Low rate of information technology in the Gaza strip local government is dedicated (Sultan, 2011). This study, therefore, considers 500 managers in the ministers of the Gaza strip-Palestine local government directory as a sampling frame to study this issue. Since the research objective is to examine the determinants of determinant of the information technology innovativeness and adoption in the local government in Gaza strip - Palestine, the unit of analysis is the organization. The targeted respondent all manager at the Palestinian ministries in the Gaza strip with grades General Director (A3), General Director (A4), Deputy Director (A), Unit managers (B) and Unit manager (C) they were (922). They generally have extensive IT knowledge and the about the governmental working process and processes and they have the ability to complete the questionnaire. An online internet questionnaire is considered for the data collection. There are three sections in the survey questionnaire. The first section is designed to collect demographic information relating to the respondents such as their: age, gender, Qualification, Job Title, Years of Experience, and working Ministry. The second section collects data about the government's information technology innovativeness. The last section collects data about managements support that affecting government's information technology innovativeness. In this section, the questions have been built to proceed logically with one question linking to the next.

\section{Conclusion}

This conceptual paper discusses the determinants for government's innovativeness of information technologies in the public sector and adoption decision and explains the usage of different influence strategy may affect the role of other factors in information technology innovativeness and adoption decision. This concept paper suggests and encourages future work to examine the effect of management support to explain information 
technology innovativeness and adoption decision. In the next stage of this study, authors intend to investigate whether an influence strategy plays a significant effect of information technology innovativeness determinants to explain information technology innovativeness and adoption decision. By doing so, managers and policy makers can utilize the findings of this study to understand which factors would most likely facilitate the information technology innovativeness and adoption. In addition, the findings of this paper are to enable the managers and policy makers to manage the effects of these factors more effectively.

\section{References:}

Agbim, K. C. (2013). The relative contribution of management skills to entrepreneurial success: A survey of small and medium enterprises (SMEs) in the trade sector. International Organization of Scientific Research Journal of Business and Management, 7(1), 08-16.

Alisawi, O. (2014). Future risks to the government in Gaza. Alaqsa Chanel.

Bose, R., \& Luo, X. (2011). Integrative framework for assessing firms' potential to undertake Green IT initiatives via virtualization-A theoretical perspective. The Journal of Strategic Information Systems, 20(1), 38-54.

Bowen, F. E., Rostami, M., \& Steel, P. (2010). Timing is everything: A meta-analysis of the relationships between organizational performance and innovation. Journal of Business research, 63(11), 1179-1185.

Chahine, S., \& Goergen, M. (2013). The effects of management-board ties on IPO performance. Journal of Corporate Finance, 21, 153-179.

Chandiwana, T. (2013). An assessment of citizen benefits of enterprise resource planning systems in municipalities.

Chen, Guoquan Tjosvold, Dean Liu, \& Chunhong. (2006). Cooperative Goals, Leader People and Productivity Values: Their Contribution to Top Management Teams in China*. Journal of Management Studies, 43(5), $1177-1200$.

Cho, I., \& Kim, Y.-G. (2002). Critical Factors for Assimilation of Object-Oriented Programming Languages. Journal of Management Information Systems, 18(3), 125-156.

Denti, L., \& Hemlin, S. (2012). Leadership and innovation in organizations: A systematic review of factors that mediate or moderate the relationship. International Journal of Innovation Management, 16(03), 1240007.

El-Ghorra, M. h. d. (2011). the influence of knowledge sharing on the level of innovation" a field study for managers at the palestinian ministries in the gaza strip. islamic university of Gaza, 326(23).

Elbanna, A. (2013). Top management support in multiple-project environments: an in-practice view. European Journal of Information Systems, 22(3), 278-294.

Elenkov, D. S., Judge, W., \& Wright, P. (2005). Strategic leadership and executive innovation influence: An international multi-cluster comparative study. Strategic management journal, 26(7), 665-682.

Gatautis, R. (2015). The impact of ICT on public and private sectors in Lithuania. Engineering Economics, 59(4).

Kapoor, K. K., Dwivedi, Y. K., \& Williams, M. D. (2014). Rogers' innovation adoption attributes: a systematic review and synthesis of existing research. Information Systems Management, 31(1), 74-91.

Kim, Dong Kumar, Vinod Kumar, \& Uma. (2012). Relationship between quality management practices and innovation. Journal of Operations Management, 30(4), 295-315.

Makri, M., \& Scandura, T. A. (2010). Exploring the effects of creative CEO leadership on innovation in hightechnology firms. The Leadership Quarterly, 21(1), 75-88.

Manna, A. Q. (2012). Evaluation of the role of top management in achieving synergy between organizational structure and information technology in communications and banking sectors. Doctoral theses, Amman Arab University, Jordan, 210(22).

Mason, P. L. (2015). Diffusion of Electronic Health Records in Rural Primary Care Clinics. WALDEN UNIVERSITY.

Mergel, I. (2013). Social media adoption and resulting tactics in the US federal government. Government Information Quarterly, 30(2), 123-130.

Mergel, I., \& Bretschneider, S. I. (2013). A three - stage adoption process for social media use in government. Public administration review, 73(3), 390-400.

Michel, J. G., \& Hambrick, D. C. (2002). Diversification posture and top management team characteristics. Academy of Management Journal, 35(1), 9-37.

Popovič, A., Hackney, R., Coelho, P. S., \& Jaklič, J. (2012). Towards business intelligence systems success: Effects of maturity and culture on analytical decision making. Decision Support Systems, 54(1), 729-739.

Rashidi, M. N., Begum, R. A., Mokhtar, M., \& Jacqueline, J. (2014). Criteria towards Achieving Sustainable Construction Through Implementation of Environmental Management Plan (EMP). Advanced Review on Scientific Research, 1(1), 43-64.

Ryan, J. C., \& Tipu, S. A. (2013). Leadership effects on innovation propensity: A two-factor full range leadership model. Journal of Business research, 66(10), 2116-2129. 
Schechter, C. B., Walker, E. A., Ortega, F. M., Zonszein, J., Chamany, S., \& Silver, L. D. (2015). Costs and Effects of a Telephonic Diabetes Self-Management Support Intervention Using Health Educators. Journal of Diabetes and its Complications.

Sharma, Srinarayan Rai, \& Arun. (2003). An assessment of the relationship between ISD leadership characteristics and IS innovation adoption in organizations. Information \& Management, 40(5), 391-401.

Shokralla, S., Spall, J. L., Gibson, J. F., \& Hajibabaei, M. (2012). Next - generation sequencing technologies for environmental DNA research. Molecular ecology, 21(8), 1794-1805.

Sultan, S. S. (2011). Knowledge, Innovation and New Technologies for Sustainable Development: Case of the Occupied Palestinian Territory. GSTF Business Review (GBR), 1(1), 266.

Turban, E., \& Volonino, L. (2010). Business Intelligence and Decision Support Systems. Information Technology for Management: Transforming Organizations in the Digital Economy, 445-484.

Vaccaro, I. G., Jansen, J. J., Van Den Bosch, F. A., \& Volberda, H. W. (2012). Management innovation and leadership: The moderating role of organizational size. Journal of Management Studies, 49(1), 28-51.

Van der Boor, P., Oliveira, P., \& Veloso, F. (2014). Users as innovators in developing countries: The global sources of innovation and diffusion in mobile banking services. Research Policy, 43(9), 1594-1607.

Venkatesh, V., \& Bala, H. (2012). Adoption and impacts of interorganizational business process standards: Role of partnering synergy. Information systems research, 23(4), 1131-1157.

Venkatesh, V., Thong, J. Y., \& Xu, X. (2012). Consumer acceptance and use of information technology: extending the unified theory of acceptance and use of technology. MIS quarterly, 36(1), 157-178.

Wally, S., \& Becerra, M. (2001). Top Management Team Characteristics and Strategic Changes in International Diversification The Case of US Multinationals in the European Community. Group \& Organization Management, 26(2), 165-188.

West, M. A., Borrill, C. S., Dawson, J. F., Brodbeck, F., Shapiro, D. A., \& Haward, B. (2003). Leadership clarity and team innovation in health care. The Leadership Quarterly, 14(4), 393-410.

$\mathrm{Wu}$, \& Liang, H. (2008). When does internal governance make firms innovative? Journal of Business research, 61(2), 141-153.

Yigitbasioglu, O. M., \& Irani, Z. (2015). The role of institutional pressures and top management support in the intention to adopt cloud computing solutions. Journal of Enterprise Information Management, 28(4). 